33. Sulzer, M.-“ Microphtalmie unilatérale droite." Recueil d'Ophtalmologie, p. 356, 1906.

34. Harman, N. Bishop. - " New pedigrees of cataract-posterior polar, anterior polar and microphthalmia, and lamellar." Trans. Ophth. Soc., Vol. XXIX, p. $296,1909$.

35. Harman, N. Bishop.-" Ten pedigrees of congenital and infantile cataract; lamellar, coralliform, discoid, and posterior polar with microphthalmia." Trans. Ophth. Soc., Vol. XXX, p. 251, 1910.

36. Stuelp, O. - "Ueber familiären Mikrophthalmus congenitus bei 8 von 14 Geschwistern." Arch.f. Ophthal., Vol. LXXXVI, p. 136, 1913.

37. Thomsen, Chr.-_ "Ueber die Vererbung des Mikrophthalmus mit und ohne Katarakt." Inaugural - Dissertation. Rostock, 1913.

38. Ischreyt, G. - "Zur Kasuistik der Missbildungen des Auges. Mikrophthalmus." Klin. Monatsbl. f. Augenheilk., Vol. LVII, July-December, p. 504, 1916.

39. Ring, G. O.- " Concerning coloboma of the iris in association with congenital cataract." Ophthalmic Record, March, 1917, ref. Arch. of Ophthalm., Vol. XLVI, p. 392, 1917.

ADDITIONAL LITERATURE REFERRED TO.

1. Roll, G. W.-_" Microphthalmos." Trans. Ophthal. Soc., Vol. XXIII, p. 398, 1903, and Ophthalmic Review, p. 177, 1903.

2. Brailey, W. A.- "Double Microphthalmos with defective development of iris, teeth and anus. Glaucoma at an early age.". Trans. Ophthal. Soc., Vol. X, p. 139, 1890.

3. Nieden, A. - "Vier Fälle von Coloboma vag. nervi optici ohne weitere Spaltbildung." Arch.f. Augenheilk., Vol. VIII, p. 22

4. Pyle.- " Microphthalmos, extensive colobomata and other congenital defects." Ophthal. Record, p. 211, 1908.

5. Becker, F.- "Microphthalmos." (Verein d. Aerzte Dusseldorf's). Deutsche med. Wochenschr., p. 485 (Nagel's Jahresb., 1907).

6. Donders, F. C.- "Accommodation and Refraction of the Eye." The New Sydenham Society, London, Vol. XXII, p. 89, 1864.

7. Mayou, S. - " Microphthalmos resembling glioma with lenticonus and hypertrophy of the ciliary body." Trans. Ophthal. Soc., Vol. XXVIII, p. $107,1908$.

8. Querenghi, Fr._-" Microptalmo Congenito con stafiloma posteriore progressivo." Annali di Ottalm., Vol. XVI, p. 190, 1887. (Nagel's Jahresb., 1887).

9. Posey, William C.- " Report of two unusual forms of congenital cataracts," Ophthalmic Record, p. 150, Vol. XIX, 1910.

10. Schultze, O. - "Ueber Albinismus und Mikrophthalmie." Phys. - med. Gesellsch. zu Würzburg. Ref. Münchener med. Wochenschr., p. 2445, 1505.

11. Best, F.- "Korectopie." Arch.f. Ophthal., Vol. XL, Part iv, p. 198. Leipzig, 1894.

\title{
A LETTER FROM BENJAMIN GIBSON OF MAN- CHESTER ON THE SUBJECT OF THE PUBLICATION OF HIS BOOK
}

BY

R. R. JAMES

LONDON.

THE following letter, which has recently come into my hands, may be of interest to readers of the BRITISH JOURNAL OF Ophthalmology. Addressed to Messrs. Cadell \& Davies, Booksellers, London, it runs as follows :-

Manchester, October 22, 1810.

GentLEMEN,

By the recommendation of my friend Dr. Ferriar, I address you, 
respecting a small volume, which I am about to publish and which is now ready for the press. The subject of it is surgical : consisting of several of the finer operations upon the eye, which, as far as I know, have not until now been laid before the public; the knowledge of them being confined to a few of my surgical friends. For the merits of the work I refer you to Dr. Ferriar, or to Dr. Henry of this place, who have both read the manuscript. With respect to - its length, I think that it will extend to about 140 pages or more, printed of the same size as Dr. Ferriar's Medical Histories. I intend to have it printed at Warrington, that I may correct the press myself. Attached to the work there will be two plates; one of instruments in outline only. The other, which consists of four drawings of eyes, may either be executed in the usual style of engraving, or be coloured, whichever you most approve of ; provided you chuse to publish the work.

And now, Gentlemen, with respect to terms: I do not wish to dispose of the copyright, nor do I publish for any pecuniary profit. If, therefore, after making proper enquiries of the merits of the performance, you are willing to take the whole expense upon yourselves and allow me thirty copies (many of which will be given where the book would not have been bought) you are welcome to print any kind of edition of it you please, and receive any profits arising from its sale. I shall be glad to receive as early an answer as your leisure will permit; and if I have omitted any points of information, upon a business I am unacquainted with, I shall be ready to add them.

I remain, Gentlemen,

Yours very respectfully,

B. Gibson.

This letter is endorsed on the back, as follows :-

SIR,

London, October 26, 1810.

We are favoured with your obliging letter, and are very ready to undertake the publication in question, on the terms proposed. You will be so kind then as to direct the printers (Mr. Haddock, probably) to print 500 copies, in a manner similar to that of Dr. Ferriar's new edition; and, with regard to the plates, we request the engravings may be executed in whatever way you may judge best.

We are, Sirs,

Your obliged and very obedient servants.

The book in question is the "Practical Observations on the formation of an Artificial Pupil, with remarks on the extraction of Soft Cataract, through a puncture in the Cornea," by B. Gibson. 8 vo. London, 1811. It was printed by Haddock, of Warrington, 
and there is a copy in the Bowman Library, a presentation copy from the author to James Wardrop.

Benjamin Gibson was born at Newcastle-on-Tyne in 1784 . After having received his general education at Richmond, Yorkshire, he was apprenticed to Mr. Ingham, surgeon, of Newcastle-on-Tyne, and in 1796, he was in London, studying under Mathew Baillie. $\mathrm{He}$ went to Manchester, as assistant to the celebrated surgeon, Charles White, in 1799. Gibson was surgeon to the Manchester Infirmary, 1804-1812; he was also assistant surgeon to the Royal Manchester and Salford Volunteer Regiment of Infantry. He suffered from consumption, and died at Ardwick, March 6, 1812. These few facts about him are extracted from Brockbank's "Honorary Medical Staff of the Manchester Infirmary, 1752-1830."

\title{
CONGENITAL ABSENCE OF THE LENS, WITH SPECIAL REFERENCE TO AN APHAKIC HUMAN EMBYRO*
}

BY

\author{
I. C. MANN, M.B., B.S.,
}

RESEARCH STUDENT IN THE INSTITUTE OF PATHOLOGY AND RESEARCH, ST. MARY'S HOSPITAL.

CONGENITAL absence of the lens is of such rare occurrence that some observers have denied that it is ever found apart from gross malformations such as anophthalmos and severe degrees of microphthalmos. From time to time, however, cases have been reported clinically, but have not been verified by microscopic examination. All these cases, as far as I am aware, occurred in America, and the first was reported by Baker in 1887. The details in this case are so meagre that very little information can be gained from the account. Since then other cases have been reported by Cherryholmes (1902), Adams, Hardy and Sherer (1915). In Cherryholmes' case there was microphthalmos with an interpupillary distance of only $1 \frac{7}{8}$ inch, and also nystagmus, convergent strabismus and amblyopia.

Cases of microphthalmos which have been subjected to microscopic examination are many, and in the majority of them (for example, Wiegel's case of microphthalmos and atypical vitreous) the lens could be identified, though it was often only represented by a few degenerate epithelial cells enclosed in a much wrinkled capsule. Cases in which it was entirely absent were usually those severe degrees of failure of development in which all that could be found of the eye was a cyst or vesicle of entirely atypical structure, or

* Read on May 13, 1921, before the Section of Ophthalmolsgy of the Royal Society of Medicine. 